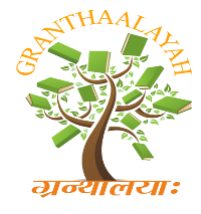

\author{
INTERNATIONAL JOURNAL OF RESEARCH - \\ GRANTHAALAYAH \\ A knowledge Repository
}

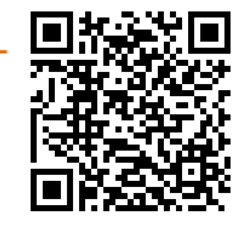

Social

\title{
THE USE OF POP-UP DICTIONARY FOR ENGLISH VOCABULARY LEARNING FOR PRIMARY SCHOOL LEVEL
}

\author{
Nutthida Prasarntong ${ }^{* 1}$, Nutprapha K. Dennis ${ }^{2}$ \\ ${ }^{* 1,2}$ English Department, Graduate School, Ubon Ratchathani Rajabhat University, THAILAND
}

DOI: https://doi.org/10.29121/granthaalayah.v4.i7.2016.2613

\section{ABSTRACT}

The purpose of this study was to study students' opinions toward using Pop-up Dictionary to enhance English vocabulary learning. The instruments of the study were 1) Pop-Up Dictionary 2) questionnaire. The researcher chose all students in Pratomsuksa 5 to be population. The methodologies of this study were 1) Set the objectives and goals of the study. 2) Study English curriculum and choose the contents for creating the material. 3) Design research methodology. 4) Construct the research instruments, the lesson plans, an observation form, and the questionnaire. Then, let the experts check the research instruments. 5) Students study by using Pop-up, teacher observes the students' behavior and lets the students take the questionnaire, respectively. 6) Evaluate and analyze the students' scores from the questionnaire. The research findings indicated that: The students' opinion about vocabulary learning by using Pop up Dictionary pointed that the students' behaviors were sometimes motivated to be better". Moreover, many students suggested that they want to learn by using Pop-Up Dictionary. It shows that many students had positive attitude to learn vocabulary by using Pop-Up Dictionary.

Keywords:

Pop-up Dictionary; English vocabulary learning; Vocabulary teaching.

Cite This Article: Nutthida Prasarntong, and Nutprapha K. Dennis, "THE USE OF POP-UP DICTIONARY FOR ENGLISH VOCABULARY LEARNING FOR PRIMARY SCHOOL LEVEL" International Journal of Research - Granthaalayah, Vol. 4, No. 7 (2016): 213-219.

\section{INTRODUCTION}

In Thai society, the curriculum at all levels requires Thai student to study English beginning at elementary education to higher education. Nonetheless, English learning and teaching in Thai still have to improve because most students' English studying achievement is lower than the criteria. The cause of this problem may come from various factors. One of the reasons is because of the ineffective teaching method (Uttrarachai 2000: unpaged). There may not be enough materials for the students. So, the students may be bored because nothing motivated them to learn English. 
Vocabulary is central to a language and is critically important to the typical language learners However, teaching and learning vocabulary have been neglected in second language acquisition throughout its varying stages. After decades of neglect, lexis, which is now recognized as central to any language acquisition process, has gradually become a focus today. Vocabulary is no longer victim of discrimination in second language learning research. Because researchers have found that vocabulary problems frequently interfere with communication, and communication often breaks down when learners lack necessary vocabulary. Learners and experienced English teachers also know very well how important vocabulary is (Zimmerman, 1997: unpaged).

Most Thai students cannot use English language for communication in their daily life because of the lack of vocabulary learning. They do not understand what they read because they do not know the meaning of the words. Finally, the students cannot communicate by using vocabulary that they have studied. Moreover, many students do not want to learn English because they think that English is too difficult for them. So, the researcher believes that vocabulary is the most important part in learning English and the need for the students' attitude towards learning English to be improved.

As a consequence, English vocabulary teaching has become a necessity. A highly important aspect in English teaching is teacher must positively motivate the students. Teaching material is the best stimulation of learning, it makes the students want to learn and moreover, the students gain knowledge easily. Using Pop-up Dictionary is one way to solve students' problem in vocabulary learning because it helps teachers in motivating and developing students' vocabulary learning. It is believed that pictures can help teachers motivate the students. They can also direct and increase students' attention to relevant information (Zavah and Baken 1997: 46-47). Moreover, Pop-up Dictionary is also a new learning and teaching resource that the most students have never seen before; it can be used to motivate students' attention. For these reasons, the researcher decided to study the students' interaction in the class of English vocabulary learning by using Pop-up Dictionaries.

Purposes of the Study: The purpose of this research is to study students' opinions toward using Pop-up Dictionary to enhance English vocabulary learning.

Scope of the Study: This study focused on only 20 students' opinions toward using Pop-up Dictionary to enhance their English vocabulary learning. The data collection process took place at Saowanit School, Phosai district, Ubon Ratchathani. The results of the result will not be representative of all primary school levels in Thailand.

Significance of the Study: This study will be beneficial to English teachers who teach English vocabulary at primary school level because Pop-up Dictionary helps motivate students to learn English. The Pop-up dictionary motivates students to learn English more with positive attitude. It can be applied to English teaching in all level at Saowanit School. 


\section{MATERIALS AND METHODS}

Subjects of the Study: The subjects for this study composed of 20, grade 5 students who study the first semester of the academic year 2014 at Saowanit School in Phosai district, Ubon Ratchathani province.

Research Procedures: The study procedures are as follow:

1) Set the objectives and goals of the study.

2) Studied English subject curriculum and chose the contents for creating the material.

3) Designed research methodology.

4) Constructed the research instruments; lesson plans and a questionnaire.

5) The research instruments were reviewed and commented by experts with expertise related to English learning and teaching field.

6) After revising research instruments according to experts' comments, researcher started teaching according to the lesson plan.

7) Students used Pop-up Dictionary to learn English, then teacher observed students' behavior and completion of the questionnaire, respectively.

8) Researcher collected and analyzed data from the questionnaire.

9) The results from the questionnaire, after analyzed, were described and explained as quantitative and qualitative data.

Research Instruments: Two research instruments were used in this study. They were a Pop-up dictionary and a questionnaire. The contents in Pop-up Dictionary were selected from the students' textbooks. These included fruits, colors, body parts, numbers, occupations, animals, sports, weather and seasons. The researcher studied about the curriculum of English learning then chose the topics of Pop up Dictionary. After that, the researcher constructed Pop up Dictionary for using in English class. The questionnaire was used to investigate students' opinions toward using Pop-up Dictionary to learn English vocabulary. It was divided into 2 parts. The first part consisted of 10 questions with 5 point-rating scales. The second part of, the questionnaire was open-ended questions that were used to ask for some suggestions and comments for further improvement of Pop-up Dictionary.

Data Collection: During the lessons, teacher recorded and took notes toward students' performances about how to use Pop-up Dictionary to learn English vocabulary. After the teacher finished teaching, the students were given the questionnaires to investigate their opinions toward the use of Pop-up Dictionary.

Data Analysis: The data from teachers' notes was analyzed as qualitative data. The data from questionnaire was analyzed as quantitative data using mean scores, percentage and S.D. values for interpretation and conclusion.

\section{RESULTS AND DISCUSSIONS}

Demographic data of the students: The demographic data in this research was composed of a mixed gender of the students. According to this research, the respondents were comprised of $60 \%$ males and $40 \%$ females. 
The Score of Students' Opinions Questionnaire: Mean score of students' opinions questionnaire is 63.65 out of 75 , that is $84.86 \%$. Mode score is 65 and median is 63.50 . These scores show that the students had positive opinion and had good attitude about using Pop-up Dictionary in learning.

The Result of the Students' Opinions Questionnaire by Using Pop-up Dictionary for English Vocabulary Learning: The result of the study is in the table 3.1

Table 3.1: The Result of the Students' Opinions Questionnaire by Using Pop-up Dictionary for English Vocabulary Learning

\begin{tabular}{|c|c|c|}
\hline Student opinion & $\underline{\overline{\mathbf{X}}}$ & Interpretation \\
\hline $\begin{array}{l}\text { 1. I think that pop-up dictionary help me to pay more } \\
\text { attention to the teacher. }\end{array}$ & 3.45 & Sometimes \\
\hline $\begin{array}{l}\text { 2. I think learning English vocabulary using pop-up } \\
\text { dictionary is very interesting. }\end{array}$ & 3.55 & Sometimes \\
\hline $\begin{array}{l}\text { 3. I think that pop-up dictionary motivate me to participate } \\
\text { activities in the classroom more. }\end{array}$ & 3.50 & Sometimes \\
\hline $\begin{array}{l}\text { 4. An English lesson related to pop-up dictionary motivates } \\
\text { me to find the meaning of new words. }\end{array}$ & 3.45 & Sometimes \\
\hline $\begin{array}{l}\text { 5. An English lesson related to pop-up dictionary motivates } \\
\text { me to learn how to write new words correctly. }\end{array}$ & 3.30 & Sometimes \\
\hline $\begin{array}{l}\text { 6. An English lesson related to pop-up dictionary motivates } \\
\text { me to learn how to read new words correctly. }\end{array}$ & 3.40 & Sometimes \\
\hline $\begin{array}{l}\text { 7. An English lesson related to pop-up dictionary motivates } \\
\text { me to try to answer teacher's questions. }\end{array}$ & 3.70 & Sometimes \\
\hline $\begin{array}{l}\text { 8. Learning English vocabulary using pop-up dictionary } \\
\text { motivate me to learn English by myself after class. }\end{array}$ & 3.50 & Sometimes \\
\hline $\begin{array}{l}\text { 9. Learning English vocabulary using pop-up dictionary } \\
\text { encourage me to finish assignment and turn in on time. }\end{array}$ & 3.45 & Sometimes \\
\hline $\begin{array}{l}\text { 10. Learning English vocabulary using pop-up dictionary } \\
\text { motivate me to finish all the assignments. }\end{array}$ & 3.10 & Sometimes \\
\hline$\overline{\mathbf{X}}$ & 3.44 & \\
\hline
\end{tabular}

From the table 3.1, the data shows the students' opinions about Pop up Dictionary after they had learnt from it. The questionnaire was managed by the teacher for asking the students' opinions. The results of the questionnaire were discussed as follows:

1) The first question reflected the students' opinion level of paying attention when they had learnt vocabulary by using Pop up Dictionary. The mean score was 3.45 . It can be interpreted that Pop up Dictionary sometimes made the students pay more attention to the teacher.

2) The second item asked about the students' interest regarding Pop up Dictionary. According to the mean score 3.55, the students sometimes displayed a very interest in Pop-up Dictionary.

3) The third item asked the students' participation. The mean score was at 3.50. It can be interpreted that learning by using Pop up Dictionary sometimes inspired the students increase their activities participation in classroom. 
4) The fourth item asked the motivation to use Pop up Dictionary to find meaning of new vocabulary. The mean score was at 3.45. It can be interpreted that Pop up Dictionary sometimes motivated the students to find the meaning of new words correctly.

5) The fifth item asked the motivation of Pop up Dictionary to learn how to write new words correctly. The mean score was at 3.30. It can be interpreted that Pop up Dictionary sometimes motivated the students to write new words correctly.

6) The sixth item asked the motivation of Pop up Dictionary to learn how to read new words correctly. The mean score was at 3.40. It can be interpreted that Pop up Dictionary sometimes motivated the students to pronounce new vocabulary correctly.

7) The seventh question asked about the students' motivation to answer teacher's questions. The mean score was at 3.70 and can be interpreted that the students sometimes were motivated to try to answer the teacher's questions.

8) The eighth item of the questionnaire wanted to know about while the teacher used Pop up Dictionary for teaching, did it motivate the students to learn English by themselves after classroom or not. The mean score was at 3.50. It can be interpreted that sometimes the students had been motivated to learn by themselves.

9) The ninth item asked if using Pop-Up Dictionary for learning English vocabulary were the students encouraged to finish their assignment and turn it in on time or not. The mean score was at 3.10 that mean the students sometimes had been encouraged to finish assignment and turn in on time.

10) The last item wanted to know if learning English vocabulary using Pop-up dictionary motivated the students to finish all the assignments or not. From the mean score 3.45, can be interpreted that the students sometimes finished all assignments.

From these result the mean scores of all item was 3.44, which reflected that the subjects had good opinion and positive attitude after they had learnt using Pop up Dictionary.

Moreover, the questionnaire was used to find more information concerning the students' opinions whether the students had any suggestions and the students' feeling about Pop-Up Dictionary as below:

- The students want Pop-Up Dictionary be able to speak.

- The students want the teacher use Pop-Up Dictionary in English teaching.

- The students want Pop-Up Dictionary be able to speak and teacher use Pop-Up Dictionary in everyday teaching.

- The student wants the teacher create the Pop-Up Dictionary about fruit.

- The students want the teacher to create the various kind of vocabulary in Pop-Up Dictionary.

- The students love to study from Pop-Up Dictionary very much.

From these results, the researcher found that using Pop-Up Dictionary in English vocabulary learning helped learners attended to their studies and complete their assignments. Moreover, most learners also wanted to learn English by using Pop-Up Dictionary. The student suggestions show that many students had positive opinion and good attitude to learn vocabulary by using Pop-Up Dictionary. 


\section{CONCLUSIONS \& RECOMMENDATIONS}

\section{CONCLUSION}

The study attempted to find answers to the research question: What are students' opinions toward using Pop-up Dictionary to enhance English vocabulary learning? The population for this study was composed of 20 people of Pratomsuksa 5 students at Saowanit School in Phosai District of Ubon Ratchathani Province in the first semester of the academic year 2014. The researcher has studied by using Pop up Dictionary in English class. Two research instruments were used in this study. They were a Pop-up dictionary and a questionnaire. The data from questionnaire was analyzed as quantitative data using mean scores, percentage and S.D. values for interpretation and conclusion. The result of the study is the students' opinions in English vocabulary learning by using Pop up Dictionary is positive opinion. According to the result of the study, the subjects had better behavior when studying from Pop up Dictionary in English class. They had found new words from textbook, paid attention to the teacher, participated, and enjoyed learning in the class. They could pronounce and read vocabularies correctly. They asked, answered the teacher and friends' questions and helped friends in the class, when they did not understand words. They also repeated the new vocabulary for remembering new words, tried to guess the meaning of vocabulary, and learnt new words by themself. Moreover, they did teacher's assignment, finished assignment on time and wrote down new vocabulary in notebook too. It can be concluded that the use of Pop-Up Dictionary technique was effective in improving the students' ability to make better behavior and have good attitude in learning English. In addition, the researcher found that most students had some limitations in their writings; students used some ungrammatical sentences and some of them had problems with pronunciation the words. However, they tried to use many ways to solve the problems, for example, discussing with friends, asking the teacher, and using the dictionary.

Accordingly many researchers have suggested that using picture books to help teaching vocabulary was possibly advantageous and effective. This research was used for motivating the students to learn English vocabulary because the researcher believe that picture can help the children to learn new vocabulary easier than learn from only words. Moreover, pictures are useful and advantageous in promoting the students' attitudes, cognitive gains, and provide them the concept of learning vocabulary strategy. The researcher had adapted the picture to be Pop-up Dictionary for creating more interesting of materials and made more attractive than using only textbook to learn English.

\section{RECOMMENDATIONS}

From the study, the researcher found some limitations in this study and would like to make recommendations to further study as follows:

\section{LIMITATIONS OF THIS STUDY}

1) Pop up Dictionary can motivate the students at the beginning of teaching. So, the teacher should support other material for teaching in the same class.

2) The content in Pop up Dictionary was not related to the students' needs. Teacher should allow the students communicate their needs related to study, especially in selecting groups of words. Vocabulary should also depend on the students interest that may lead more successful completion in learning. 
3) The study did not emphasize the study for the students' grammatical structures, thus the students were taught only pronunciation and meaning of the words.

4) There were not enough Pop up Dictionaries for all the students, thus the students had to use Pop up Dictionary in groups. Teacher should create more Pop up Dictionary.

\section{RECOMMENDATIONS FOR FURTHER STUDY}

1) In a further study, the researcher should also construct several tasks or activities, such as games, rhymes, songs, and dramas because when the students have done the similar tasks a certain number of times, they may pay less attention and be easily bored with the tasks.

2) Pop up Dictionary can be used for many skills: speaking, writing, reading, grammatical. Teacher can adapt to take other information into Pop up Dictionary depend on teacher using. Moreover, Pop-up book also can be adapted to use in the other subject.

\section{ACKNOWLEDGEMENTS}

This study would not have been completed without the generous help from many people. First of all, I would like to express my deep appropriation to my adviser, Dr. Nootprapa K. Dennis who advised and guided, have contributed to the completion of this independent study. I would like to express my thankfulness and appreciation for all of the kind support from my Prasarntong family, my friends from the university, my colleagues from Saowanit school and I would like to thank you the Pratomsuksa 5 students at Saowanit school who provided useful information in this research.

\section{REFERENCES}

[1] Aebersold, J.A. and Field, L.M. From reader to reading teacher. Cambridge:Cambridge University Press, 1997, unpaged.

[2] Beaty, J.J. Picture Book Storytelling Literature Activities for Young Children. Ft. Worth, Tex.: Harcourt Publishers Ltd, 1994, unpaged.

[3] Foil, C.R., and Alber, S.R. Fun and effective ways to build students'vocabulary. Intervention in School and Clinic, 2002, unpaged.

[4] Pop art New York post. (online) December 21, 2008. Available from : http:// www.nypost.com/seven/12312006/entertainment/pop_art_entertainment_ billy_heller.htm. The Social Sciences Association of Thailand Press, 1963.

[5] Tatum, B. Using Pictures to Increase Comprehension, in Article Template Encyclopedia of Educational Technology. USA. : San Diego State University Press, 1998, unpaged.

[6] Uttrarachai, A. The Effects of Self-Access Learning Materials on Students' Listening Comprehension Development. Independent Study M.Ed. Mahasarakham, Mahasarakham University, 2000, unpaged.

[7] Zavah, F.E. and Baken, J.P. The Role of Picture Books, TESOL Journal. 7(1) ; Autumn, 1997, 46-47.

[8] Zimmerman, B.C. Historical Trends in Second Language Vocabulary Instruction. Cambridge: Cambridge University, 1997,unpaged. 